\title{
MEDIASI DALAM PENYELESAIAN SENGKETA PADA MASYARAKAT HUKUM ADAT
}

\author{
Wayan Resmini', Abdul Sakban²
}

\author{
${ }^{1}$ Pendidikan Pancasila dan Kewarganegaraan, Universitas Muhammadiyah Mataram, wayanresmini@ymail.com \\ ${ }^{2}$ Pendidikan Pancasila dan Kewarganegaraan, Universitas Muhammadiyah Mataram, sakban.elfath@yahoo.co.id
}

\begin{tabular}{l} 
INFO ARTIKEL \\
Riwayat Artikel: \\
$\begin{array}{l}\text { Diterima: } \quad 25-F e b r u a r i- \\
2018 \\
\text { Disetujui: } 26-M a r e t-2018\end{array}$ \\
\hline
\end{tabular}

Kata Kunci:

Mediasi

Sengketa

Masyarakat Hukum Adat

\section{A. LATAR BELAKANG}

Masyarakat saat ini dihadapkan pada berbagai pilihan penyelesaian sengketa sesuai dengan tingkat kepentingan dan pemenuhan kebutuhan dasarnya dalam memandang sengketa itu sendiri. Sengketa dapat diselesaikan melalui mekanisme litigasi, nonlitigasi, maupun advokasi. Masing-masing mekanisme penyelesaian tersebut memiliki persyaratan, karakteristik, dan kekuatan berlakumya yang satu

\begin{abstract}
Abstrak: Pengadilan, oleh masyarakat tidak lagi dilihat sebagai lembaga penyelesaiain sengketa satu-satunya. Saat ini keberadaan lembaga pengadilan sudah terindikasi dengan berbagai kasus korupsi, kolusi, dan nepotisme, yang lebih dikenal dengan istilah KKN. Hal ini mengingat banyak produk keputusan pengadilan yang menyimpang dari asas-asas keadilan, cepat dan berbiaya murah. Dalam konteks inilah diperlukan model alternative penyelesaian sengketa pada masyararakat hukum adat yang lebih efisien, adil serta akomodatif guna menjaga kelesterian dan keberlanjutan kehidupan masyarakat hukum adat, yang lebih manusiawi dan berkeadilan. Tradisi penyelesaian sengketa pada masyarakat hukum adat didasarkan pada nilai filosofi kebersamaan (komunal), pengorbanan, nilai supernatural, dan keadilan. Dalam masyarakat hukum adat kepentingan bersama merupakan filosofi hidup yang meresap pada setiap anggota masyarakat adat. Pelaksanaan hasil mediasi yang sudah disakralkan dihadapan tokoh adat, apalagi sudah dilakukan dengan suatu upacara adat (ritual), maka kesepakatan tersebut harus dilaksanakan dengan segera, bila salah satu pihak mengingkari atau tidak bersedia melaksanakan hasil mediasi, maka pihak tersebut akan mendapatkan sanksi adat dari masyarakat hukum adat. Sanksi adat diberikan atas pertimbangan, bahwa pengingkaran kesepakatan damai merupakan bentuk pengingkaran terhadap nilai dan rasa keadilan masyarakat hukum adat. Penjatuhan sanksi adat dijatuhkan oleh tokoh adat yang bertindak sebagai penjaga nilai keadilan dan warisan leluhur dalam masyarakat hukum adat.
\end{abstract}

\begin{abstract}
The court, by the community is no longer seen as the only dispute resolution agency. At present the existence of a court institution has been indicated by various cases of corruption, collusion and nepotism, which are better known as KKN. This is because there are many products of court decisions that deviate from the principles of justice, fast and low cost. In this context an alternative model of dispute resolution is needed in the customary law community that is more efficient, fair and accommodative in order to maintain the sustainability and sustainability of the life of indigenous peoples, who are more humane and just. The tradition of dispute resolution in indigenous peoples is based on the values of communal philosophy, sacrifice, supernatural values, and justice. In indigenous peoples the common interest is a life philosophy that permeates every member of the indigenous community. The implementation of the mediation results that have been sacred before traditional leaders, moreover has been done with a traditional ceremony (ritual), then the agreement must be carried out immediately, if one party denies or is unwilling to carry out the mediation results, the party will get customary sanctions from the community customary law. Customary sanctions are given for consideration, that the denial of a peace agreement is a form of denial of the values and sense of justice of indigenous peoples. The imposition of customary sanctions is imposed by traditional leaders who act as guardians of the value of justice and ancestral heritage in indigenous and tribal peoples.
\end{abstract}

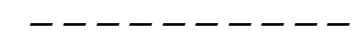


dihadapan publik, sifatnya perdata dan terdapat keinginan yang kuat dari masing-masing pihak untuk berdamai dan memusyawarahkan kasusnya. Keputusan yang dihasilkan lebih bersifat sukarela. Sedangkan, mekanisme advokasi dapat didayagunakan untuk sengketa di masyarakat yang tidak sekedar pada masalah perebutan hak dan kepastian hak semata, tetapi lebih dari itu memiliki implikasi dan dimensi yang sangat mendalam dan luas bagi keberlanjutan ekonomi, social, budaya, politik, dan keamanan masyarakat.Misalnya sengketa adat, perburuhan, lingkungan hidup, perempuan dan anak korban kekerasan dan perdagangan (trafficking).

Pengadilan, oleh masyarakat tidak lagi dilihat sebagai lembaga penyelesaiain sengketa satu-satunya. Lebihlebih saat ini keberadaan lembaga pengadilan sudah terindikasi dengan berbagai kasus korupsi, kolusi, dan nepotisme, yang lebih dikenal dengan istilah KKN. Lebih parah lagi, lembaga ini oleh masyarakat telah diberi stigma "Mafia Peradilan". Hal ini mengingat banyak produk keputusan pengadilan yang menyimpang dari asas-asas keadilan, cepat dan berbiaya murah. Dalam konteks inilah diperlukan model alternative penyelesaian sengketa pada masyararakat hukum adat yang lebih efisien, adil serta akomodatif guna menjaga kelesterian dan keberlanjutan kehidupan masyarakat hukum adat, yang lebih manusiawi dan berkeadilan. Model alternative penyelesaian sengketa adalah teknik mediasi.

\section{B. METODE PENELITIAN}

Jenis penelitian ini tergolong dalam penelitian hukum empirik yaitu penelitian yang mengkaji hukum, sebagai norma yang pasif dan juga mengkaji hukum dan peraturan dan implementasinya[1]. Adapun pendekatan yang digunakan penelitian ini[2] adalah sebagai berikut:

1. Pendekatan social-legal yaitu suatu pendekatan yang memperhatian keberlakuan/penerapan aturan-aturan hukum dalam masyarakat, sehingga diketahui perbedaan antara hukum yang berlaku (das sollen) dengan pelaksanaan di lapangan (das sain).

2. Analytical and conceptual approach (pendekatan analisis konsep) yaitu melakukan pendekatan hukum adat dan sanksi adat yang berlaku dalam masyarakat.

3. Historical approach (pendekatan sejarah) yaitu pendekatan dengan mengkaji peraturan-peraturan yang sudah berlaku, tentang keberadaan awig-awig dan sejarah penguasaan serta system hukum yang dipergunakan dalam menjaga ketertiban anggota masyarakat.

Dimana data dan informasi yang akan dikumpulkan baik dari segi pengkajiannya maupun dari segi pengelolaannya dilakukan secara interdisipliner dan multidisipliner serta lintas sektoral. Data sekunder berupa bahan hukum primer, sekunder dan tersier serta informasi tersebut kemudian dianalisis secara yuridis kualitatif dengan mendalam sehingga diperoleh gambaran mengenai hukum adat. Studi kasus digunakan untuk mengkaji secara mendalam dan intensif satu kelompok sasaran subjek penelitian dengan mengacu kepada fakta materiel berupa orang, tempat, waktu dan segala yang menyertainya. Metode pengumpulan data yang digunakan adalah kepustakaan, pengamatan, wawancara, dan analisis dokumen. Kemudian analisis data menggunakan deskriptif analitis untuk menguraikan data lapangan dengan studi literatur dengan pendekatan perundang-undangan dan pendekatan konseptual.

\section{HASIL DAN PEMBAHASAN}

\section{Mediasi}

Istilah mediasi cukup gencar dipopolerkan oleh para akademisi dan praktisi akhir-akhir ini. Para ilmuan berusaha mengungkap secara jelas makna mediasi dalam berbagai literatur melalui riset dan studi akademik. Para praktisi juga cukup banyak menerapkan mediasi dalam praktek penyelesaian sengketa. Perguruan Tinggi,Lembaga Swadaya Masyarakat (LSM), dan berbagai lembaga lain cukup banyak menaruh perhatian pada mediasi ini. Tetapi untuk dijadikan pegangan beberapa pengertian mediasi akan didiskripsikan pada penjelasan di bawah ini.

Secara etimologi, istilah mediasi berasal dari bahasa latin, mediare yang berarti berada ditengah. Makna ini menunjuk pada peran yang ditampilkan pihak ketiga sebagai mediator dalam menjalankan tugasnya menengahi dan menyelesaikan sengketa antara para pihakada, Berada di tengah juga bermakna mediator harus berada pada posisi netral dan tidak memihak dalam menyelesaikan sengketa.Mediator harus mampu menjaga kepentingan para pihak yang bersengketa secara adil dan sama, sehingga menumbuhkan kepercayaan (trust) dari para pihak yang bersengketa.

Dalam Collins English Dictionary and Thesaurus disebutkan bahwa mediasi adalah suatu kegiatan yang menjembatani antara dua pihak yang bersengketa guna menghasilkan kesepakatan (agreement)[3]. Kegiatan ini dilakukan oleh mediator sebagai pihak yang ikut membantu mencari berbagai alternatif penyelesaian sengketa. Posisi mediator dalam hal ini adalah mendorong para pihak untuk mencapai kesepakatankesepakatan yang dapat mengakhiri perselisihan dan persengketaan. Mediator tidak dapat memaksa para pihak untuk menerima tawaran penyelesaian sengketa darinya. Para pihaklah yang menentukan kesepakatankesepakatan apa yang mereka inginkan. Mediator hanya membantu mencari alternatif dan mendorong mereka secara bersama-sama ikut menyelesaikan sengketa.

Dalam Kamus Besar Bahasa Indonesia, kata mediasi diberi arti sebagai proses pengikutsertaan pihak ketiga dalam suatu perselisihan sebagai penasehat[4]. Pengertian mediasi dalam hal ini mengandung tiga unsur penting yaitu: Mediasi merupakan proses penyelesaian perselisihan atau sengketa yang terjadi antar dua pihak atau lebih, Pihak yang terlibat dalam penyelesaian sengketa adalah pihak-pihak yang berasal dari luar pihak yang bersengketa, Pihak yang terlibat dalam penyelesaian tersebut bertindak sebagai 
penasehat dan tidak memiliki kewenangan apa-apa dalam pengambilan keputusan.

Ahli lain berpendapat bahwa pengertian mediasi adalah proses negosiasi pemecahan sengketa dimana pihak luar atau pihak ketiga yang tidak memihak (impartial) bekerja sama dengan pihak yang bersengketa untuk membantu memperoleh kesepakatan perjanjian dengan memuaskan[5]. Difinisi lain menyebutkan, mediasi adalah intervensi terhadap suatu sengketa atau negosiasi oleh pihak ketiga yang dapat diterima, tidak berpihak dan netral tidak mempunyai kewenangan dalam mengambil keputusan dalam membantu para pihak yang berselisih dalam upaya mencapai kesepakatan secara sukarela dalam penyelesaian permasalahan yang disengketakan[6].

Di Indonesia, Pengertian mediasi secara lebih konkrit dapat ditemukan dalam Peraturan Mahkamah Agung Republik Indonesia No 02 Tahun 2003 tentang Prosedur Mediasi di Pengadilan. Mediasi adalah penyelesaian sengketa melalui proses perundingan para pihak dengan dibantu oleh mediator (Pasal 1 butir 6). Mediator adalah pihak yang bersifat netral dan tidak memihak, yang berfungsi membantu para pihak dalam mencari berbagai kemungkinan penyelesaian sengketa (Pasal 7 butir 5).

Berdasarkan uraian tersebut di atas dapat disimpulkan beberapa elemen yang mewujudkan proses mediasi, yaitu: 1) Penyelesaian sengketa bersifat sukarela, 2)Terdapat intervensi atau bantuan pihak ketiga netral yang tidak berpihak, 3) Pengambilan keputusan diserahkan oleh para pihak secara consensus, 4) Proses pengambilan keputusan dilakukan secara partisipasif.

\section{Tujuan Mediasi}

Tujuan mediasi adalah untuk (1) menghasilkan suatu rencanaatau kesepakatan ke depan yang dapat diterima dan dijalankan oleh para pihak yang bersengketa, (2) mempersiapkan para pihak yang bersengketa untuk menerima konsekwensi dari keputusan yang mereka buat, dan (3) mengurangi kekhawatiran dan pengaruh negatif lain dari suatu sengketa dengan cara membantu pihak yang bersengketa untuk mencapai penyelesaian secara consensus.

3. Peran, Fungsi dan Tipe-tipe Mediator

a. Peran mediator

Mediator dapat mengambil peran lemah (pasif) atau peran kuat (aktif). Peran mediator lemah apabila hanya melaksanakan (1) penyelenggaraan pertemuan, (2) pemimpin diskusi netral, (3) pemelihara atau penjaga aturan perundingan agar proses perundingan berlangsung secara bertahap, (4) mengendalikan emosi para pihak, dan (5) pendorong pihak yang kurang mampu mengemukakan pandangannya.

Mediator dapat mengambil peran kuat apabila dalam perundingan mengerjakan hal-hal berikut: (1) mempersiapkan dan membuat notulen perundingan, (2) merumuskan kesepakatan para pihak, (3) membantu para pihak agar menyadari bahwa sengketa bukanlah pertarungan untuk dimenangkan, melainkan diselesaikan, (4) menyusun dan mengusulkan alternatif pemecahan masalah, dan (5) membantu para pihak menganalisis alternatif pemecahan masalah.

\section{b. Fungsi Mediator}

Fungsi Mediator mencakup tujuh hal yang mendasar, yakni: (1) sebagai katalisator, membangun suasana yang konstruktif bagi diskusi, (2) sebagai pendidik berusaha memahami aspirasi prosedur kerja, keterbatasan politis dan kendala usaha dari para pihak, (3) sebagai penterjemah, berusaha menyampaikan dan merumuskan usulan pihak yang satu kepada pihak yang lainnya melaluibahasa atau ungkapan yang baik dengan tanpa mengurangi sasaranyang dicapai oleh pengusul, (4) sebagai nara sumber, mendayagunakan informasi yang tersedia, (5) sebagai penyandang berita buruk, meredam sikap emosional pihak yang bersengketa dengan cara mengadakan pertemuan terpisah, guna menampung berbagai usulan-usulan, (6) sebagai agen realita, member pengertian secara jelas kepada para pihak yang bersengketa bahwa usulannya tidak masuk akal sehingga mempersulit terjadinya kesepakatan, dan (7) sebagai kambing hitam, siap disalahkan bila terjadi kesalahan dalam membuat kesepakatan hasil perundingan.

\section{c. Tipe-tipe Mediator}

Dalam penyelesaian sengketa melalui lembaga mediator terdapat beberapa tipe mediator, yaitu mediator hubungan sosial, mediator aotoritatif, mediator mandiri.

Tipe mediator hubungan sosial sering ditemukan dalam masyarakat pedesaan. Misalnya, para pemuka adat, pemuka masyarakat, alim ulama atau tokoh masyarakat lainnya. Orang-orang tersebut, pada umumnya memiliki wibawa atau karisma serta disegani oleh masyarakat setempat. Semua nasehat dan perkataannya dituruti setra diikuti oleh masyarakat Sehingga penyelesaian sengketa dilatarbelakangi karena adanya rasa segan dan rasa takut, rasa tidak enak jika tidak menerima keputusan tersebut.

Mediator autoritatif, adalah mediator yang bekerja di instansi pemerintah. Mediator seperti ini sering dijumpai dalam kasus tanah dan perburuhan, dan pencemaran lingkungan hidup yang melibatkan masyarakat di satu sisi dengan pengusaha di sisi lainnya.

Mediator mandiri adalah mediator yang dianggap mediator terbaik atau professional bila dibandingkan dengan mediator lainnya. Mediator mandiri tidak memiliki hubungan, baik secara langsung maupun tidak langsung dengan para pihak yang bersengketa. Umumnya mediator mandiri bersifat professional.

4. Mediasi dalam penyelesaian sengketa pada masyarakat Hukum Adat Mediasi

Secara antropologis setiap orang dalam suatu komunitas memiliki sistem dan mekanisme penyelesaian sengketa. Bagi sebagian masyarakat Indonesia yang hidup di pedesaan dan juga merupakan masyarakat adat jika timbul sengketa diantara mereka jarang sekali dibawa ke pengadilan negara untuk diselesaikan. Mereka lebih suka dan dengan senang hati membawa sengketa ke lembaga yang tersedia pada masyarakat adat untuk diselesaikan secara damai. Dalam masyarakat hukum adat penyelesaian sengketa biasanya dilakukan dihadapan kepala desa atau di depan hakim adat

Secara historis kultur masyarakat Indonesia sangat menjunjung tinggi pendekatan konsensus. Pengembangan penyelesaian sengketa sesuai dengan mekanisme pengambilan keputusan secara tradisional dan penyelesaian sengketa secara adat. Proses penyelesaian sengketa secara koopetatif sudah dilakukan sejak dahulu oleh masyarakat adat. Misalnya pada masyarakat adat Batak, penyelesaian sengketa memiliki nilai religious yang masih mengembangkan forum ranggun adat yang intinya penyelesaian sengketa secara musyawarah dan kekeluargaan. Demikian halnya dengan lembaga penyelesaian sengketa di Bali, juga di 
Minangkabau dikenal adanya lembaga hakim perdamaian yang secara umum perperan sebagai mediator dan konsiliator. Konsep pembuat keputusan pada masyarakat pedesaan di Jawa didasarkan atas prinsip musyawarah mufakat dibuat oleh keseluruhan yang hadir dalam forum rembug desa sebagai suatu kesatuan. Makna sengketa dalam masyarakat hukum adat, ditujukan pada ketidakseimbangan sosial, jika terjadi sengketa dalam masyarakat hukum adat, maka masyarakat hukum adat merasakan adanya ketidakseimbangan yang terjadi dalam kehidupan masyarakat hukum adat.Oleh karena itu masyarakat hukum adat akan menyelesaikannya melalui mekanisme hukum adat.

Hukum adat sebagai suatu sistem hukum memiliki pola tersendiri dalam menyelesaikan sengketa.Hukum adat memiliki karakter tersendiri dan khas dibandingkan dengan sistem hukum yang lain. Hukum adat lahir dan tumbuh dari masyarakat, sehingga keberadaannya tidak dapat dipisahkan dengan masyarakat. Hukum adat tersusun dan terbangun atas nilai, kaidah atau norma yang disepakati dan diyakini kebenarannya oleh komunitas masyarakat adat, serta memiliki relevansi kuat dengan karakter, nilai, dan dinamika yang berkembang dalam masyarakat hokum adat.

Hukum adat Indonesia merupakan penjelmaan dari kebudayaan masyarakat Indonesia dan bersandar pada alam pikiran bangsa Indonesia yang berbeda dengan alam pikiran sistem hukum Barat atau system hukum lainnya. Soedarsono, menyebutkan bahwa tata hukum adat Indonesia berbeda dengan tata hukum lainnya yang ada di Indonesia seperti tata hukum Romawi yang dibawa colonial Belanda ke Indonesia (Barat), tata hukum Hindu India, tata hokum Islam, dan berbagai tata hokum lainnya[7]. Perbedaan tata hukum adat Indonesia dngan tata hukum lain sangat wajar terjadi, karena masyarakat Indonesia sebagai pendukung budaya mempunyai pandangan dan falsafah hidup masyarakat tersendiri. Soepomo, menyebutkan bahwa hukum adat merupakan penjelmaan dan perasaan hokum yang nyata dari rakyat[8]. Hukum adat dibangun dari bahan kebudayaan baik yang bersifat riil maupun idiil dari bangsa Indonesia khususnya dan bangsa melayu pada umumnya.

Dalam suatu komunitas setiap orang memiliki sistem dan mekanisme penyelesaian sengketata. Bagi sebagian masyarakat Indonesia hidup di pedesaan yang merupakan masyarakat adat jika timbul sengketa diantara mereka jarang sekali dibawa ke pengadilan Negara untuk diselesaikan. Mereka lebih suka dan senang hati membawa sengketa ke lembaga yang tersedia pada masyarakat adat untuk diselesaikan secara damai.Dalam masyarakat hokum adat penyelesaian sengketa biasanya dilakukan dihadapan kepala desa atau hakim adat. Perlu diketahui karena secara secara historis kultur masyarakat Indonesia sangat menjunjung tinggi pendekatan consensus. Pengembangan penyelesaian sengketa di Indonesia sesuai dengan mekanisme pengambilan keputusan secara tradisional dan penyelesaian sengketa secara adat.

Di Indonesia, proses penyelesaian sengketa dengan memperhatikan nilai-nilai yang terdapat dalam masyarakat adat yang berjiwa kooperatif. Hal tersebut dapat dilihat dari cara menyelesaian sengketa yang dilakukan oleh masyarakat adat Batak misalnta, memiliki nilai religious yang masih mengembangkan forum ranggut adat yang intinya penyelesaian sengketa secara musyawarah dan kekeluargaan. Di Minangkabau dikenal adanya lembaga hakim perdamaian yang secara umum berperan sebagai mediator dan konsoliator. Sedangkan konsep pembuatan keputusan pada masyarakat pedesaan di Jawa didasarkan atas prinsip musyawarah mufakat dibuat oleh keseluruhan yang hadir dalam forum rembug desa sebagai suatu kesatuan.

Dalam perkembangannya, masyarakat Indonesia berada dipersimpangan jalan, tradidi dari masyarakat agraris (pedesaan) ke masyarakat industri (perkotaan), hal ini menyebabkan terjadinya benturan-benturan nilai. Nilai tradisional yang dipegang oleh generasi dulu mulai luntur. Sedangkan nilai-nilai baru (modern) belum sepenuhnya terbentuk dan diterima.

Sengketa yang terjadi saat ini, antara lain terdiri atas (1) sengketa tradisional (berkisar tentang keluarga, warisan, dan tanah atau sumberdaya alam), (2) sengketa bisnis yang rumit serta syarat dengan unsure keuangan, perbankan modern, peraturan perundang-undangan, etika profesi, pemenuhan kontrak dan sebagainya., (3) sengketan lingkungan yang rumit dengan masalah pembuktian ilmiah dan hubungan administrasi pusat dan daerah, dan (4) sengketa ketenagakerjaan yang diwarnai dengan masalah hak asasi manusia, reputasi Negara dan perhatian masyarakat internasional.

Gambaran tersebut di atas mengarah pada kebutuhan yang tepat dalam menangani masalah sengketa yang terjadi dalam masyarakat hukum adat, masyarakat hukum adat dalam penyelesaian sengketa adat selalu memperhatikan prinsip-prinsip yang telah diwariskan.

Prinsip-prinsip yang telah lama dijalankan oleh banyak komunitas masyarakat adat di Indonesia dalam penyelesaian sengketa adat antara lain:

a. Negosiasi atau berunding merupakan salah satu cara yang tersedia dimana negosiasi memberikan peluang kepada para pihak untuk menentukan pilihanpilihannya. Dalam negosiasi para pihak tidak bergantung pada norma hokum yang kaku dan tertulis dalam kitab undang-undang ataupun berbagai peraturan laimmya.Selain itu negosiasi juga memberikan ruang bagi para pihak untuk bias menang secara bersama-sama. Dalam negosiasi tidak ada yang kalah dan yang menang. Semua pihak memperoleh kesempatan untuk menjelaskan berbagai persoalan dalam proses negosiasi.

b. Mediasi atau dalam bahasa inggris disebut mediation adalah penyelesaian sengketa dengan menengahi. Mediator adalah orang yang menjadi penengah.Mediasi adalah proses penyelesaian sengketa yang memerlukan bantuan pihak ketiga yang netral dalam upaya negosiasi dalam penyelesaian sengketa.Dalam hal mempergunakan mediasi diperlukan beberapa elemen yang diperlukan dalam mewujudkan proses mediasi antara lain: (a). penyelesaian sengketa bersifat sukarela, (b). terdapat intervensi atau bantuan pihak ketiga yang netral dan tidak memihak, (c). pengambilan keputusan diserahkan pada para pihak secara consensus, (d). proses pengambilan keputusan dilakukan secara partisipasif[9].

Memahami tradisi penyelesaian sengketa dalam masyarakat hukum adat, perlu dipahami filosofi dibalik terjadinya sengketa dan dampak-dampak yang terjadi akibat terhadap nilai dalam komonitas masyarakat 
hukum adat. Filosofi ini sangat penting diketahui, agar dapat memahami keputusan-keputusan yang diambil oleh pemegang adat (tokoh adat) dalam menyelesaikan sengketanya. Pertimbangan filosofi yang didasarkan pada pandangan hidup menjadi amat penting, karena dapat mengukur tingkat keadilan, ketentraman, pengorbanan dan kesejahteraan yang akan dirasakan oleh masyarakat hukum adat, atas keputusan yang diambil tersebut[10].

Tradisi penyelesaian sengketa pada masyarakat hukum adat didasarkan pada nilai filosofi kebersamaan (komunal), pengorbanan, nilai supernatural, dankeadilan. Dalam masyarakat hokum adat kepentingan bersama merupakan filosofi hidup yang meresap pada dada setiap anggota masyarakat adat. Kepentingan bersama dijunjung tinggi yang melebihi kepentingan individu, sehingga dalam masyarakat adat dikenal adanya kepentingan bersama. Sengketa yang terjadi antar individu maupun antar kelompok, dalam pandangan masyarakat hukum adat adalah tindakan yang mengganggu kepentingan bersama (komunal), oleh karenanya harus cepat diselesaikan secara arif dengan menggunakan pola penyelesaian adat[11].

Filosofi Pengorbanan dalam penyelesaian sengketa menjadi penekanan dalam masyarakat hukum adat, parapihak yang bersengketa harus rela mengobankan kepentingan individual demu untuk kepentingan komunal. Penyelesaian sengketa dengan pola adat, mencerminkan nilai komunalitas yang mesti diterima oleh individu yang bertikai, dengan kesadaran bahwa mereka adalah bagian dari yang lain. Keputusan hokum adat yang diambil dalam penyelesaian sengketa adalah paying yang menjaga dan mempertahankan nilai dan tatanan adat yang mereka junjung tinggi demi mempertahankan kebersamaan dan kesamaan. Kesediaan berkorban untuk kepentingan bersama akan mendapat penghormatan dan nilai etika yang lebih dari masyarakat hukum adat, sebaliknya pihak yang tidak mempertimbangkan kepentingan komunal cendrung mendapat penilaian negative dari masyarakat hokum adat, dan akan dikenakan sanksi adat.

Filosofi supernatural, penyelesaian sengketa dalam masyarakat hokum adat diidentifikasi dalam bentuk upacara-upacara ritual. Tujuannya agar pihak yang bersengketa perlu mendapat pengakuan dari supernatural dalam penyelesaiannya. Oleh karena itu, adanya nilai supernatural menandakan bahwa penyelesaian sengketa mendapat persetujuan dan pemantauan dari Yang mahakuasa, sehingga para pihak yang bertikai tidak leluasa untuk kembali bertikai setelah sengketa diselesaikan melalui pola adat.

Filosofi keadilan yang ingin ditegakkan dalam penyelesaian sengketa pada masyarakat hukum adat adalah keadilan komunal yaitu keadilan damana tidak ada yang merasa dirugikan dengan keputusan yang diambil ketua atau tokoh adat dalam penyelesaian sengketa. Keadilan ini amat penting ditegakkan sebagai sendi dari tatanan kehidupan masyarakat hukum adat. Hukum adat diberlakukan dalam rangka menegakkan keadilan masyarakat. Semakin tinggi nilai keadilan komunal diwujudkan, maka semakin kuat dan mulia kedudukan masyarakat hukum adat tersebut. Esensi penyelesaian sengketa dalam hukum adat adalah mewujudkan damai dalam arti yang komprehensif. Damai yang dimaksud disini adalah damai secara keseluruhan. Oleh karena itu pendekatan yang dipergunakan adalah pendekatan persuasive untuk menyelesaikan sengketa dengan menggunakan bahasa adat dan agama, sehingga muncul kesadaran dari para pihak bahwa tidak ada artinya hidup di dunia bila terjadi persengketaan dan tindakan yang merugikan orang lain. Tujuan penyelesaian sengketa dalam hukum adat adalah perwujudan damai yang permanen.

Masyarakat hukum adat lebih mengutamakan jalur musyawarah dalam penyelesaian sengketa,yang bertujuan untuk mewujudkan kedamaian dalam masyarakat. Jalur musyawarah merupakan jalur utama yang digunakan masyarakat hukum adat dalam penyelesaian sengketa, karena dalam musyawarah akan dapat dibuat kesepakatan damai yang menguntungkan kedua belah pihak. Penggunaan jalur musyawarah bukan berarti mematikan proses penyelesaian sengketa melalui jalur peradilan adat. Penyelesaian sengketa baik melalui jalur musyawarah maupun jalur peradilan adat, tetap didominasi pendekatan musyawarah dalam penyelesaian sengketa, karena musyawarah merupakan salah satu filosofi dan ciri masyarakat hukum adat. Penyelesaian sengketa melalui mekanisme hokum adat dapat dilakukan melalui musyawarah yang mengambil bentuk mediasi, negosiasi. Kedua model penyelesaian sengketa ini sering diraktiktikkan masyarakat adat dalam penyelesaian sengketa mereka. Para tokoh adat menjalankan fungsinya sebagai mediator. Dalam prakteknya para tokoh adat umumnya menggunakan pendekatan ini secara bersama-sama.

Tokoh adat mendominasi penyelesaian sengketa melalui mediasi dapat digunakan untuk penyelesaian kasus-kasus seperti pembunuhan atau penganiayaan, jika terjadi penganiayaan atau pembunuhan, maka tokoh adat akan menyelesaikan kasus ini dengan melakukan pendekatan baik dengan korban dan keluarga korban maupun dengan pelaku dan keluarga pelaku. Keterlibatan pihak keluarga menjadi amat penting, karena dalam masyarakat hokum adat ikatan kekeluargaan menjadi pengikat kuat hubungan antar anggota kerabat. Oleh karenanya, jika salah seorang dari anggota kerabat melakukan tindak pembunuhan atau penganiayaan atau menjadi korban perlakuan tersebut, maka keluarga korban akan bertindak untuk mencari keadilan. Disinilah peran tokoh adat menjembatani (memediasi) guna mencari penyelesaian secara adil menurut hokum adat.

Keterlibatan tokoh adat dalam penyelesaian sengketa, tidak mengharuskan adanya ijin dari pihak keluarga yang bersengketa. Tokoh adat sebagai penjaga stabilitas dan nilai adat, dengan sendirinya berkewajiban untuk menyelesaikan sengketa tersebut, tokoh adat dapat bertindak atas inisiatif sendiriuntuk menyelesaikan sengketa, jika dianggap kasus tersebut dapat mengganggu keadilan dan nilai keseimbangan masyarakat hokum adat. Tetapi adakalanya, para pihak yang bersengketa yang meminta para tokoh adat untuk menyelesaikan sengketa mereka.

\section{SIMPULAN DAN SARAN}

Dalan masyarakat hukum adat, kesepakatan bersama yang dibuat oleh para pihak merupakan pencapaian tertinggi manusia dalam mengelola atau mengontrol nafsu amarahnya. Karena dalam mediasi, mengharuskan para pihak sama-sama mundur selangkah guna samasama mencapai kemenangan. Kemampuan seperti itu 
mendapat nilai tertinggi dalam konstruksi nilai dan pandangan masyarakat hukum adat. Ciri masyarakat hukum adat tergambar dari nilai kesederhanaan dan kebersahajaan dalam wujud bila individu memiliki pribadi yang bersih dari sifat rakus, menang sendiri, dan tidak menghargai hak-hak dan pendapat orang lain.

Pelaksanaan hasil mediasi yang sudah disakralkan dihadapan tokoh adat, apalagi sudah dilakukan dengan suatu upacara adat, maka kesepakatan tersebut harus dilaksanakan dengan segera, bila salah satu pihak mengingkari atau tidak bersedia melaksanakan hasil mediasi, maka pihak tersebut akan mendapatkan sanksi adat dari masyarakat hukum adat.

Sanksi adat diberikan atas pertimbangan, bahwa pengingkaran kesepakatan damai merupakan bentuk pengingkaran terhadap nilai dan rasa keadilan masyarakat hokum adat. Penjatuhan sanksi adat dijatuhkan oleh tokoh adat yang bertindak sebagai penjaga nilai keadilan dan warisan leluhur dalam masyarakat hokum adat.

\section{UCAPAN TERIMA KASIH}

Penulis mengucapkan terima kasih kepada editor yang senantiasa memberikan saran dan masukan kepada penulis sehingga artikel ilimiah ini selesai dengan baik.

\section{DAFTAR RUJUKAN}

[1] M. Fajar and Y. Achmad, "Dualisme penelitian hukum normatif dan empiris," Yogyakarta: Pustaka Pelajar, 2010.

[2] M. Sulastriyono and S. D. F. Aristya, "Penerapan Norma Dan Asas-Asas Hukum Adat Dalam Praktik Peradilan Perdata," Mimb. Huk., vol. 24, no. 1, pp. 2540, 2012.

[3] C. M. Gilmour, Lorna, Penny Hand, Collins English Dictionary and Thesaurus, Third. Great Britain: Harper Collins Publishers, 2007.

[4] K. B. B. Indonesia, "Jakarta: Depdikbud RI," 1988.

[5] S. Margono, ADR, alternative dispute resolution, \& arbitrase: proses pelembagaan dan aspek hukum. Ghalia Indonesia, 2000.

[6] C. W. Moore, The mediation process: Practical strategies for resolving conflict. John Wiley \& Sons, 2014.

[7] Soedarsono, Hukum Adat Dan Modernisasi Hukum. Yogyakarta: Fakultas Hukum Universitas Islam Indonesia, 1998.

[8] S. Wignjodipuro, Pengantar dan Asas-Asas Hukum Adat. Gunung Agung, 1982.

[9] R. Safa'at, "Advokasi Dan Alternatif Penyelesaian Sengketa (Latar belakang, Konsep dan Implementasinya)," Surya Pena Gemilang, Malang, 2011.

[10] H. Hilman, "Pengantar Ilmu Hukum Adat Indonesia," Mandar Maju, Bandung, 1992.

[11] B. Muhammad, Pokok-pokok hukum adat. Pradnya Paramita, 1995. 